Wiesław Golnau

ORCID: 0000-0002-8366-1626

University of Gdańsk

Faculty of Management ${ }^{1}$

\title{
Short-term impact of visa waiver for Ukrainian citizens on economic migration to Poland
}

\section{Summary}

Ukrainian citizens can work in Poland based on a work permit or a registered employer's declaration to entrust work to a foreigner. Based on the Regulation (EU) 2017/850 of the European Parliament and of the Council of 17 May 2017, they were exempted from the requirement to have a visa when crossing the external borders of the European Union. This regulation came into force on June 11, 2017 and applies to short-term stays of up to 90 days over a period of 180 days. According to some representatives of employers' organizations, this resolution is unfavourable to Polish enterprises. It may lead to Ukrainian citizens choosing to look for a job in other European Union countries in which they can get higher compensation for their work than in Poland. The purpose of this article is to determine whether the visa waiver for Ukrainian citizens has influenced their decision of working in Poland within the 6 months of introducing the new regulations, i.e. from June to December 2017. The conducted research using

1 Correspondence: Wieslaw Golnau, University of Gdańsk, Armii Krajowej 101, 81-824 Sopot, Poland; author's email address: wieslaw.golnau@ug.edu.pl. 
the natural experiment method suggests that in the short term the lifting of the visa requirement for Ukrainian citizens had a slight negative impact on their employment in Poland.

Key words: labour market, employment, migration, foreigner

\section{Introduction}

Foreigners can work in Poland after obtaining an appropriate permit. Since mid-2007, derogations from this general principle have been gradually introduced. Initially, they concerned the citizens of Ukraine, Belarus and Russia, then Georgia and Moldova, and later also Armenia. They allow short-term work by the citizens of these countries based only on the employer's declaration registered in the labour office. Simultaneously, the citizens of the above countries were also covered by simplified regulations for the issue of work permits.

The introduced facilitation of access to the Polish labour market for citizens of the six countries resulted in a gradual increase in the number of foreigners working legally in Poland. The majority of them were Ukrainians, who occupied hundreds of thousands of positions in "major" occupational groups, such as elementary occupations, craft and related trades workers, plant and machine operators and assemblers. In some workplaces, Ukrainians constituted a significant portion of employees.

In accordance with the Regulation (EU) 2017/850 of the European Parliament and of the Council of 17 May 2017 (OJ L 133, 2017 pp. 1-3), Ukrainian citizens holding a biometric passport were exempted from the requirement to have a visa when crossing the external borders of the European Union, with the exception of Great Britain and Ireland. Although the introduced visa-free regime covers only short-term stays, lasting up to 90 days over a period of 180 days, it can have a significant impact on the decision of Ukrainians to take up employment in European Union countries other than Poland. As a result of this regime, they can freely move around the entire European Union in search of work. Thus, one of the administrative barriers to access to the labour markets of the most developed countries of the European Union has been removed. The visa-free regime introduced for Ukrainian citizens, however, is not so important for their activity on the Polish labour market, as they have already obtained the aforementioned rights to work in Poland. According to some labour market specialists and employers' representatives, the abolition of the visa requirement may have serious consequences for the labour market situation in Poland. Before the introduction of the visa-free regime, Poland was an attractive country for Ukrainians in terms of wages and salaries, as in some jobs those were even five times higher than in Ukraine. After the introduction of the visa-free regime, Ukrainians may attempt to obtain a job 
(not necessarily legal) in countries other than Poland such as Germany, the Netherlands, or France, where wages and salaries are even several times higher than in Poland. Thus, a shortage of employees may occur on the Polish labour market, especially in lowpaid areas of the economy and in low-paid professions (IAR, 2017; Ośrodek Studiów Wschodnich, 2017, p. 4).

The purpose of this article is to determine whether the lifting of the visa requirement for Ukrainian citizens affected their decision of whether to work in Poland, within the 6 months of introducing the new regulations, i.e. from June to December 2017. Extension of the research period was not possible, as at the beginning of 2018 changes in the regulations regarding taking up work by Ukrainian citizens in Poland came into force. As a result, statistical data available for 2018 is not comparable with the data from previous years.

This article consists of four parts. The first discusses how employees make decisions about labour migration. This section explains that the earnings that can be obtained outside the home country are not the only option considered. The second part of the article addresses the rules under which foreigners can work in Poland. Against the background of general rules covering all foreigners, the rules applicable to Ukrainian citizens were indicated. The regulations applicable until the end of 2017, as well as those implemented at the beginning of 2018, were considered. The third part presents the method used for the author's research. It is a natural experiment that allows for determining the short-term effects of changes in the applicable law, regulating issues such as employment. The last part of the article contains the results of the author's research. The natural experiment was carried out according to the assumptions resulting from legal regulations discussed in the second part of the article. Data from the Ministry of Family, Labour and Social Policy were used to conduct it.

\section{Determinants of individual migration decisions}

From an economic perspective, employee migration is a form of investment in human capital, which consists of knowledge, skills and experience possessed by individuals. Migration requires certain expenditures from the individual that can bring a certain return on investment in their qualifications. When deciding on labour migration, employees consider the amount of earnings available to them on the current and alternative markets and the costs associated with a possible change of residence. On this basis, they determine the present value of net benefits in various markets. A person will opt for migration only if the present value of the expected increase in earned income exceeds the present value of the costs associated with the migration. The present value of net benefits of migration is usually calculated using the formula (Borjas, 2016, p. 313; Ehrenberg, Smith, 2012, pp. 324-325; McConnell et al., 2006, p. 278): 


$$
V_{b}=\sum_{n=1}^{N} \frac{D_{2}-D_{1}}{(1+r)^{n}}-\sum_{n=1}^{N} \frac{K}{(1+r)^{n}}-Z
$$

where:

$V_{b}$ - present value of net benefits of migration,

$D_{2}$-earned income from future job in year n,

$D_{1}$ - earned income from current job in year n,

$N$-length of time (in years) expected to work at future job,

$r$-rate of discount,

$n$-year in which incomes and costs accrue,

$K$-monetary costs resulting from the change of residence in year n,

$Z$-non-monetary costs resulting from change of residence.

When $V_{b}>0$, a person decides to migrate because the expected increase in earned income exceeds the sum of monetary and non-monetary costs of investment in human capital. However, when $V_{b}<0$, the person will decide against migration. Assuming a constant value for all factors other than the earned income, the greater the difference between the earned income from future work and the earned income from current work, the higher the present value of net benefits will be.

Figure 1 shows four typical streams of earned income of a certain person in subsequent years after a possible migration. The $\mathrm{w}_{\mathrm{d}}$ curve indicates the future earned income of the employee in question which he or she expects to achieve in the current workplace. It constitutes a reference to the earned incomes available to this employee in three different countries to which he or she can migrate. The $\mathrm{w}_{\mathrm{k} 1}$ curve predicts a lower earned income in country 1 from the start of the first job on emigration until reaching the retirement age. It applies to people whose qualifications do not meet the needs of employers and who are unable to develop them properly. The $\mathrm{w}_{\mathrm{k} 2}$ curve indicates a lower earned income in country 2 only in the early years after migration. We encounter such a situation when, as a result of migration, an employee loses a large part of their specific human capital, useful in work performed in the country of origin, which, however, can be supplemented as a result of investments after a few years spent on emigration (Filer et al., 1996, p. 256). The $\mathrm{w}_{\mathrm{k} 3}$ curve does not demonstrate this type of loss in country 3 . It provides for a higher earned income from starting work on emigration until retirement. Since undertaking this job guarantees the highest earned income throughout the entire professional career after possible migration, the employee in question will prefer it. If, however, in country 4 , he or she could receive an even higher earned income, the curve indicating it in Figure 1 would be above the curve $\mathrm{w}_{\mathrm{k} 3}$. That employee will then prefer to work in country 4 (e.g. in Germany) instead of country 3 (e.g. in Poland). 


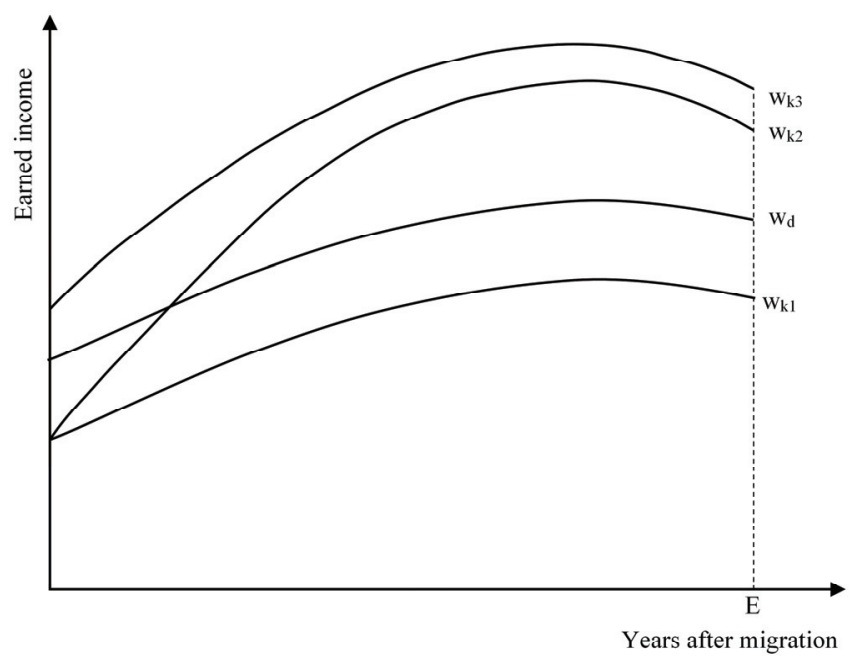

E-retirement age

$\mathrm{w}_{\mathrm{d}}$-assumed earned income in the country of origin

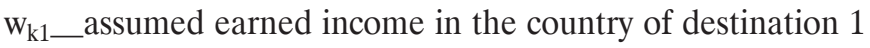

$\mathrm{w}_{\mathrm{k} 2}$-assumed earned income in the country of destination 2

$\mathrm{w}_{\mathrm{k} 3}$-assumed earned income in the country of destination 3

Figure 1. Profiles of earned income in the country of origin and three different destination countries

Source: own elaboration based on Filer et al., 1996, p. 257.

The decision on possible migration, apart from the amount of the future earned income, is also dependent on the associated costs. These include monetary and non-monetary costs (Sjaastad, 1962, pp. 83-87). Monetary costs include expenses of obtaining information about the new place of residence and work, traveling to the country of destination and transportation of personal belongings, food and accommodation when changing jobs, and traveling to the country of origin to visit relatives and friends. Whereas non-monetary costs consist of the lost earned income while traveling to the country of destination, looking for a new job, learning a new profession, as well as the loss of future retirement benefits, psychic costs resulting from the separation from close persons and well-known surroundings and the necessity to stay in an unknown and potentially hostile environment.

The difference between the earned income from future and current work and the costs associated with the migration depend on several factors, which thus affect the decisions of individuals about a possible migration to another country. These include the age of the employee, his or her education, family status, distance between countries of destination and origin, situation on the labour market and the dispersion of earnings. Young people are more likely to migrate because they have many years of work ahead of them, during which they can get an appropriate return on investment in human capital in the form 
of migration. It is different in the case of older people who have less time to regain the invested funds. Older people usually have a greater amount of specific human capital that can only be used in the current workplace and is not useful in another country. Thus, by deciding to migrate, they would lose part of their human capital, which influences the amount of earnings in their country of origin. In addition, older employees bear higher non-monetary migration costs in the form of unpaid retirement benefits. Finally, older people are usually more rooted in the social environment. Losing contact with close persons is associated with greater psychic costs for them, than in the case of young people (Borjas, 2016, p. 316; McConnell et al., 2006, pp. 278-279).

Better educated people are more willing to decide on economic migration, because the geographical area of the labour market relevant to this type of people is larger than for less educated people. In addition, the differences in the amount of earnings available for well-educated people in different markets are larger. Better educated people decide to migrate more often also because the knowledge of foreign languages among these people is greater and they can acquire and analyse information about potential jobs outside the country faster, which reduces the costs of migration.

The decision on the possible migration of the whole family forces its members to assess the investment in human capital from the perspective of the earned income and costs of all its members. Therefore, a family in which both spouses receive high earnings in the country of origin is unlikely to migrate. Single people or families with only one working spouse are more likely to migrate. Schoolchildren reduce migration, as the psychic costs associated with leaving their current place of residence will be high (Mincer, 1978, pp. 749-773).

The increase in the distance between the country of origin and the country of destination reduces the propensity to migrate. This relationship exists because as the distance separating the places increases, both monetary and non-monetary migration costs increase. Monetary costs are rising, as obtaining information about a distant workplace requires greater outlays. Travel costs to this place and visits of relatives and friends in the years after migration are also higher. A greater distance also causes higher psychic costs arising as a result of leaving the current place of residence, as frequent contacts with close persons are not possible (Schwartz, 1973, pp. 1153-1169). People deciding to migrate to distant countries attempt to reduce the resulting costs. They do so by using the knowledge and experience of people who had previously made the same decision. This way "chain migration" arises, which means a gradual movement of more people from the same area of origin to the same region in the country of destination. This process allows limiting many migration costs related to e.g. obtaining information on vacancies or renting the first place of accommodation. Moving to larger ethnic groups also reduces psychic costs, as it enables frequent contact with people with similar lifestyles.

The decision on possible migration may be affected by the situation on the labour market in both the country of origin and the country of destination. When the head of the family is unemployed in the country of origin and has the prospect of getting a well-paid job in another country with a lower unemployment rate and a large number of vacancies, it will positively influence the decision on migration, as these factors are important for the 
earned income stream in the following years of a professional career (McConnell et al., 2006, p. 281).

In the case of countries with similar average earnings, the distribution of employees by earnings may influence the decision on possible economic migration. Figure 2 shows the theoretical distribution of employees in two countries A and B in which the average earnings are identical, however, country A has a smaller dispersion of earnings than country B. The greater part of the people employed in this country receive earnings close to the average and the smaller part are low earners and high earners. As a consequence, a person with a high, above average human capital can expect higher earnings in country B (amounting to e.g. $\mathrm{w}_{1}$ ) than in country A (amounting to e.g. $\mathrm{w}_{2}$ ) provided that they will be in the same place of the earnings distribution of the employees (marked e.g. X). On the other hand, a person with lower-than-average human capital can expect higher earnings in country A (amounting to e.g. $\mathrm{w}_{3}$ ) than in country B (amounting to e.g. $\mathrm{w}_{4}$ ) when they will be in the same position of earnings distribution of the employees (marked e.g. X). As a consequence, if there are similar average earnings in two countries, and the relative earnings in these countries are positively correlated, people with above average human capital will be willing to migrate from a country with a smaller dispersion of earnings to a country with a greater dispersion of earnings; while people with lower human capital than the average will be interested in migrating from a country with a greater dispersion of earnings to a country with a smaller dispersion of earnings (Borjas, 1987, pp. 531-553; Borjas, 1994, pp. 1667-1717; Filer et al., 1996, pp. 262-264).

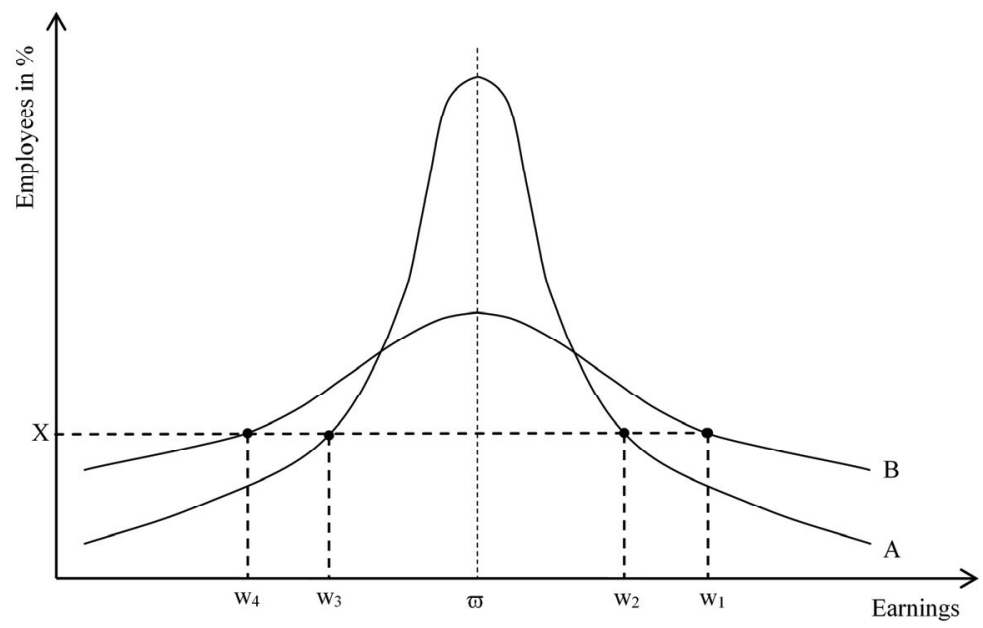

$\mathrm{v}$ - average earnings in countries A and B

A-smaller dispersion of earnings in country A

B-greater dispersion of earnings in country B

Figure 2. Impact of distribution of employees by earnings on the migration structure

Source: own elaboration based on Filer, Hamermesh, Rees, 1996, p. 263. 


\section{Legal regulations regarding taking up work by Ukrainian citizens in Poland}

Foreigners, including Ukrainian citizens, are entitled to work in Poland if they have a work permit and stay in the territory of Poland based on a residence permit entitling them to take up work (e.g. an appropriate visa or visa-free regime). Until the end of 2017, the following five types of work permits were issued (Ustawa, 2004, Art. 87 and 88; Rozporządzenie, 2015a, section 2):

1) A-in the case of foreigners who are to perform work based on a contract with an entity whose registered office is in Poland;

2) B-in the case of foreigners who are to perform work consisting in performing functions in the management board of a legal person entered in the Register of Entrepreneurs;

3) $\mathrm{C}$ - in the case of foreigners working for a foreign employer, delegated to Poland for a period longer than 30 days in a calendar year to the branch or subsidiary of a foreign entity or another entity associated with it;

4) D-in the case of foreigners working for a foreign employer who does not have any branches or subsidiaries in Poland, delegated to our country to provide a temporary, occasional service;

5) E-in the case of foreigners working for a foreign employer, delegated to Poland for a period longer than 30 days within 6 consecutive months for a different purpose than in the case of $\mathrm{B}, \mathrm{C}$ and $\mathrm{D}$ permits.

The listed types of work permits are issued by the proper voivode at the request of the entity entrusting work to a foreigner, for a specified period, not longer than 3 years (in the case of a B permit - up to 5 years) with the possibility of extension, for a specific employer and a specific foreigner and for a given position or type of work (Ustawa, 2004, Art. 88a-88f). A type A permit is issued if the foreigner's wage or salary is not lower than the wage or salary of employees performing comparable work, and the entity entrusting work to the foreigner attaches to the permit application information from the proper head of county (poviat), called starosta, about the inability to meet the staffing needs of the employer with the help of registered unemployed people or about a negative result of recruitment organized for the employer (Ustawa, 2004, Art. 88c), commonly called the labour market test. It consists of checking whether the register of the poviat labour office contains candidates who meet the requirements indicated by the employer in the job offer, and possibly referring them to the employer. If the employer refuses to accept the candidate offered to him who meets the requirements set out in the job offer without a justified reason, the starosta states that it is possible to meet the staffing needs of the given employer (Rozporządzenie, 2015a, section 5). On the other hand, if the analysis of the labour office records does not show that there is a possibility of organizing the recruitment of candidates for a given employer, the starosta issues 
information about the inability to meet the staffing needs of that employer (Ustawa, 2004, Art. 88c(2)).

The law provides for certain cases in which the information from the starosta is not required to obtain a type A work permit. First of all, this law applies to citizens of Ukraine and 5 other countries, i.e. Armenia, Belarus, Georgia, Moldova, and Russia, performing nursing and caring work or working as domestic help for natural persons in households, or also those working for at least 3 months immediately before submitting an application for a permit, working for the same entity, in the same position, based on a written contract, based on the employer's written declaration of the intention to entrust work to a given foreigner, registered by the appropriate poviat labour office (Rozporządzenie, 2009, section 3). Therefore, citizens of other countries may work in Poland in strictly defined cases without a permit. Such law applies to citizens of Ukraine, as well as Armenia, Belarus, Georgia, Moldova and Russia. It is conditioned by the employer registering in the relevant poviat labour office a declaration of the intention to entrust work to a specific foreigner in which the profession and place of work are specified, together with the date of commencement and period of work, type of contract constituting the basis for performing the work, as well as the wage or salary due to the contractor. After registering the declaration, a foreigner can apply for a visa on its basis, however, the period of service is limited to 6 months over 12 subsequent months. During this time, the foreigner may work for various employers, regardless of the number of registered declarations (Rozporządzenie, 2015b, section 1).

At the beginning of 2018, the provisions regulating the foreigners' employment in Poland were significantly changed. First of all, a type S seasonal work permit was introduced. It is issued for foreigners who are to work in Poland in the scope of activity subclasses according to the NACE rev. 2 recognized by the minister responsible for labour as seasonal, based on an agreement with the entity whose registered office is the territory of Poland (Ustawa, 2004, Art. 88(2); Rozporządzenie, 2017a, section 2; Rozporządzenie, $2017 b$ ). The proper starosta issues a seasonal work permit for a specified period, not longer than 9 months in a calendar year, provided that the wage or salary paid to the foreigner is not lower than the wage or salary of employees performing comparable work or employed in a comparable position, and the employer includes in the application for a permit for seasonal work the information from the proper starosta about the inability to meet his or her staffing needs based on the registers of the relevant poviat labour office. However, employers intending to employ citizens of Armenia, Belarus, Georgia, Moldova, Russia, or Ukraine are exempt from the requirement to provide information from the proper starosta (Ustawa, 2004, Art. 88n, 88o, 88t; Rozporządzenie, 2017c). Citizens of these countries may still take up work in Poland without a permit, based on a declaration to entrust work to a foreigner entered in the register of declarations, but only outside the scope of activity covered by seasonal work permits (Ustawa, 2004, Art. 87(3); Rozporządzenie, 2017c). 


\section{Research method}

The natural experiment method was used to determine whether the lifting of the visa requirement for Ukrainian citizens from 11 June 2017 influenced their decision to work in Poland. The idea of this method is similar to a classic experiment. In both cases, the impact of the examined factor on the set of entities constituting the treatment group is assessed. Because this group is influenced by many factors at the same time, it is necessary to use a certain procedure to isolate the influence of the factor of interest from other factors. For this purpose, apart from the treatment group, a control group is also observed. It should be influenced by the same factors as the treatment group except for the factor the significance of which is the researcher's subject of interest.

In some respects, a classic experiment is different from a natural experiment. The duration of a classic experiment remains under the control of the researcher, and the division of the examined population into the treatment group and the control group is random. On the other hand, the duration of a natural experiment and the choice of the treatment group are conditioned by an event beyond the influence of the researcher, such as a change in the law affecting the functioning of certain groups of people or organizations. In the case of a natural experiment, the choice of the treatment group and control group is not random. The researcher chooses both groups on the basis of rational premises. The condition for including a certain homogeneous (due to a specific sociodemographic criteria) population of people in the treatment group may be a change in the law regarding taking up work by foreigners in Poland, applicable to this population, however, the control group should not be influenced by the change. The impact of other factors affecting both groups should be similar. It is important that the sizes of both groups showed similar trends in several periods preceding the study of the effects of a particular change. The occurrence of divergent trends would indicate that the sizes of both groups are influenced by different factors, which could affect the results of the conducted research. In addition, the persons forming the control group should have characteristics as similar as possible to the characteristics of the persons forming the treatment group (Meyer, 1995, pp. 151-161; Tharenou et al., 2007, pp. 33-36).

Determining the effects of changing specific laws regarding foreigners' employment in Poland utilising a natural experiment is possible using a statistical procedure called difference in differences estimate (Meyer, 1995, pp. 154-155; Besley, Case, 2000, p. F673). To carry it out, statistical data describing the employment of foreigners is required. They must apply to both the treatment group and the control group in two moments-before and after the change of specific laws regarding foreigners' employment in Poland. The difference in differences is calculated according to the following formula:

$$
R R=\left(Y_{B 2}-Y_{B 1}\right)-\left(Y_{K 2}-Y_{K 1}\right)
$$

where:

$R$-consequences of changing specific laws regarding foreigners' employment in Poland for the employment of the treatment group, 
$Y_{B 2}$ - employment measure for the treatment group over a given period after the change of specific laws regarding foreigners' employment in Poland, $Y_{B 1}$ - employment measure for the treatment group over a given period before the change of specific laws regarding foreigners' employment in Poland,

$Y_{K 2}$-employment measure for the control group over a given period after the change of specific laws regarding foreigners' employment in Poland,

$Y_{K 1}$-employment measure for the control group over a given period before the change of specific laws regarding foreigners' employment in Poland.

The first part of the right side of the equation presented above expresses the effects of both the change of specific laws regarding foreigners' employment in Poland and the impact of other factors on the employment of the treatment group between two selected time ranges. In turn, the second part of the right side of this equation illustrates the hypothetical changes in employment that would occur in the treatment group between these time ranges under the influence of all factors affecting it, except for the changed specific laws. These are hypothetical changes because, in reality, they concern the control group. The difference in differences can also be calculated according to the formula:

$$
R R=\left(Y_{B 2}-Y_{K 2}\right)-\left(Y_{B 1}-Y_{K 1}\right)
$$

To calculate the difference in differences, the citizens of Ukraine were considered as the treatment group, and the citizens of Armenia, Belarus and Russia were the control group. The citizens of these four countries, as well as Georgia and Moldova, are covered by the same laws regarding foreigners' employment in Poland. However, Georgian and Moldovan citizens were excluded from the control group because they were exempted from the obligation to have visas when crossing the external borders of the European Union. In the case of Moldova, this occurred on 28 April 2014, and in the case of Georgia-on 28 March 2017. Due to the lack of reliable data on the actual employment of citizens of these countries in Poland, two other employment measures were used to conduct the research, i.e. the share of issued type A work permits for citizens of countries included in the treatment group and the control group in the total number of type A permits issued and the share of declarations registered by employers of the intention to entrust work to foreigners included in the treatment group and the control group in the total number of registered declarations. Other types of work permits were omitted, as they apply to foreigners working for a foreign employer, delegated to Poland, or performing managerial functions. It should be noted that the number of issued work permits and registered declarations of the intention to entrust work to a foreigner are greater than the number of employed foreigners, because more than one work permit can be issued for one foreigner, and the employer may register more than one declaration of the intention to entrust work to a foreigner for a specific person. The sizes of the treatment group and the control group show similar trends in the few years preceding the introduction of the visafree regime for Ukrainian citizens. Due to the fact that seasonal changes have an impact 
on the size of employment, Ukrainian citizens were exempted from the visa requirement from 11 June 2017, and on 1 January 2018 new regulations regarding the issue of work permits and registration of declarations to entrust work to a foreigner entered into force in Poland, the calculation of the difference in differences takes into account data for the second half of 2016 (before the change) and the second half of 2017 (after the change). Thus, the research conducted concerns the short-term effects of the visa waiver. The extension of this period was not possible because the statistical data necessary to carry out the calculations for 2018 are not comparable with the data from the previous years.

\section{Research results}

In the second decade of the 21st century, the worst situation on the Polish labour market occurred in 2012. According to data from the labour force survey, the number of employed persons in Poland in the last quarter of that year was 15.6 million, 1.8 million were unemployed, and vacancies at the end of the quarter were at the level of only 36 thousand (data from the demand for labour survey). The employment rate was $50.4 \%$, the unemployment rate was $10.1 \%$ and the job vacancy rate was $0.3 \%$. In the following years, there was a gradual improvement in absolute and relative figures characterising the labour market. In the last quarter of 2017, there were 16.4 million employed persons and 770 thousand unemployed in Poland. At the end of this quarter, almost 120 thousand vacancies were recorded. The employment rate increased to $53.7 \%$, the unemployment rate dropped to $4.5 \%$, while the job vacancy rate was $1 \%$.

Table 1. Type A work permits according to the citizenship of foreigners issued in Poland in 2011-2017

\begin{tabular}{|l|r|r|r|r|r|r|r|r|r|r|r|}
\hline $\begin{array}{l}\text { Citizens } \\
\text { of }\end{array}$ & $\mathbf{2 0 1 1}$ & $\mathbf{2 0 1 2}$ & $\mathbf{2 0 1 3}$ & $\mathbf{2 0 1 4}$ & $\mathbf{2 0 1 5}$ & $\begin{array}{c}\text { First } \\
\text { half of } \\
\mathbf{2 0 1 6}\end{array}$ & $\begin{array}{c}\text { Second } \\
\text { half of } \\
\mathbf{2 0 1 6}\end{array}$ & $\mathbf{2 0 1 6}$ & $\begin{array}{c}\text { First } \\
\text { half of } \\
\mathbf{2 0 1 7}\end{array}$ & $\begin{array}{c}\text { Second } \\
\text { half of } \\
\mathbf{2 0 1 7}\end{array}$ & $\mathbf{2 0 1 7}$ \\
\hline Ukraine & 17352 & 19375 & 19495 & 24945 & 48010 & 41062 & $\mathbf{6 2 ~ 1 4 6}$ & 103208 & 89787 & $\mathbf{9 9} \mathbf{5 3 4}$ & 189321 \\
\hline Armenia & 434 & 433 & 435 & 339 & 127 & 87 & $\mathbf{4 8}$ & 135 & 61 & $\mathbf{1 0 3}$ & 164 \\
\hline Belarus & 1350 & 1723 & 1723 & 1591 & 1893 & 1707 & $\mathbf{2 ~ 8 7 0}$ & 4577 & 4036 & $\mathbf{5 5 3 9}$ & 9575 \\
\hline Russia & 471 & 622 & 698 & 576 & 504 & 407 & $\mathbf{5 3 9}$ & 946 & 658 & $\mathbf{6 6 2}$ & 1320 \\
\hline Georgia & 154 & 171 & 199 & 13 & 88 & 55 & 86 & 141 & 97 & 300 & 397 \\
\hline Moldova & 977 & 609 & 596 & 897 & 1322 & 984 & 1576 & 2560 & 1856 & 1605 & 3461 \\
\hline $\begin{array}{l}\text { Other } \\
\text { countries }\end{array}$ & 15451 & 12483 & 12697 & 11677 & 9112 & 4443 & 5862 & 10305 & 8378 & 16084 & 24462 \\
\hline Total & 36189 & 35416 & 35843 & 40038 & 61056 & 48745 & 73127 & 121872 & 104873 & 123827 & 228700 \\
\hline
\end{tabular}

Source: own elaboration based on data from the Ministry of Family, Labour and Social Policy. 
In the analysed years, the number of type A work permits issued in Poland changed in line with the situation on the labour market. The fewest permits were issued in 2012 and the most in 2017 (Table 1). Their number increased 6.5 times-from 35.4 thousand up to 228.7 thousand. Most permits were issued to foreigners with Ukrainian citizenship. In 2011, Ukrainian citizens obtained $48 \%$ of the total A-type work permits issued in Poland. By 2016, this percentage had risen to $84.7 \%$, and in the last year of the research it fell to $82.8 \%$. Citizens of other countries with privileged access to the Polish labour market, listed in Table 1, were issued a much smaller share of type A work permits. Among them, the largest number of such permits was issued to Belarusian citizens. In 2011, together with the citizens of Armenia and Russia, they obtained only $6.2 \%$ of all type A work permits issued in Poland. In the following years, this percentage ranged from $4.1 \%$ in 2015 to $8.0 \%$ in 2013.

To determine whether the lifting of the visa requirement for Ukrainian citizens in June 2017 had an impact on their employment in Poland, the difference in differences test concerning type A work permits issued to Ukrainian citizens (who are the treatment group) and citizens of Armenia, Belarus and Russia (forming the control group) was conducted and its results are presented in Table 2 . The data in the table show that after lifting the visa requirement for Ukrainian citizens, the percentage of type A permits issued to them decreased and the percentage of permits issued to foreigners included in the control group increased. The test results suggest that the introduction of the visafree regime had a slightly negative impact on the number of Ukrainian citizens taking up work in Poland.

Table 2. The difference in differences test concerning type A work permits issued to Ukrainian citizens (treatment group) and citizens of Armenia, Belarus and Russia (control group) in Poland in the second half of 2016 and the second half of 2017 in \%

\begin{tabular}{|l|c|c|c|}
\hline \multicolumn{1}{|c|}{ Specification } & $\begin{array}{c}\text { Second half } \\
\text { of } \mathbf{2 0 1 6}\end{array}$ & $\begin{array}{c}\text { Second half } \\
\text { of } \mathbf{2 0 1 7}\end{array}$ & $\begin{array}{c}\text { The difference between the second half } \\
\text { of 2017 and the second half of 2016 }\end{array}$ \\
\hline $\begin{array}{l}\text { Treatment group } \\
\text { —citizens of Ukraine }\end{array}$ & 84.98 & 80.38 & -4.60 \\
\hline $\begin{array}{l}\text { Control group } \\
\text { citizens of Armenia, } \\
\text { Belarus and Russia }\end{array}$ & 4.73 & 5.09 & 0.36 \\
\hline $\begin{array}{l}\text { The difference between } \\
\text { the treatment group } \\
\text { and the control group }\end{array}$ & 80.25 & 75.29 & $\mathbf{- 4 . 9 6}$ \\
\hline
\end{tabular}

Source: own elaboration based on the data from Table 1.

Table 3 presents data on declarations of the intention to entrust work to foreigners from six countries whose citizens could be employed in Poland on this basis. In the analysed years, the least declarations-235.6 thousand-were registered in 2013. This 
constituted about 7 thousand fewer declarations than in 2012. In the following years, the number of registered declarations increased rapidly. In the last year included in the research, 1824.5 thousand of them were registered. The vast majority of employers registered declarations of the intention to entrust work to Ukrainian citizens. The share of these declarations in the total number was $91.8 \%$ in 2012, it increased to $97.5 \%$ in 2015 and decreased again to $94.0 \%$ in 2017 . The share of declarations registered for citizens of the other 5 countries was small. Declarations regarding citizens of Armenia, Belarus and Russia together constituted from $1.1 \%$ in 2015 to $3.8 \%$ in 2012 of the total number of declarations of the intention to entrust work to a foreigner registered in Poland.

Table 3. Declarations of the intention to entrust work to a foreigner according to the citizenship of foreigners registered by poviat labour offices in Poland in 2011-2017

\begin{tabular}{|c|c|c|c|c|c|c|c|c|c|c|c|}
\hline $\begin{array}{c}\text { Citizens } \\
\text { of }\end{array}$ & 2011 & 2012 & 2013 & 2014 & 2015 & $\begin{array}{c}\text { First } \\
\text { half of } \\
2016\end{array}$ & $\begin{array}{c}\text { Second } \\
\text { half of } \\
2016\end{array}$ & 2016 & $\begin{array}{c}\text { First } \\
\text { half of } \\
2017\end{array}$ & $\begin{array}{c}\text { Second } \\
\text { half of } \\
2017\end{array}$ & 2017 \\
\hline Ukraine & 239646 & 223671 & 217571 & 372946 & 762700 & 614196 & 648649 & 1262845 & 904854 & 810037 & 1714891 \\
\hline Armenia & $\mathrm{X}$ & $\mathrm{X}$ & $\mathrm{X}$ & 774 & 1043 & 667 & 930 & 1597 & 1224 & 1562 & 2786 \\
\hline Belarus & 4370 & 7636 & 5194 & 4017 & 5599 & 7939 & 15461 & 23400 & 24216 & 33830 & 58046 \\
\hline Russia & 963 & 1624 & 1260 & 1227 & 1939 & 1825 & 2112 & 3937 & 2694 & 3456 & 6150 \\
\hline Georgia & 1774 & 1384 & 2343 & 2103 & 1366 & 679 & 1019 & 1698 & 1980 & 9146 & 11126 \\
\hline Moldova & 13024 & 9421 & 9248 & 6331 & 9575 & 9015 & 11635 & 20650 & 12949 & 18516 & 31465 \\
\hline Total & 259777 & 243736 & 235616 & 387398 & 782222 & 634321 & 679806 & 1314127 & 947917 & 876547 & 1824464 \\
\hline
\end{tabular}

Source: own elaboration based on data from the Ministry of Family, Labour and Social Policy.

On the basis of the above data, a difference in differences test was conducted, the results of which are presented in Table 4. They are consistent with the results of the difference in differences test carried out for the type A work permits. After the change of the analysed laws regarding foreigners' employment, the percentage of registered declarations of the intention to entrust work to foreigners with Ukrainian citizenship decreased and the percentage of declarations regarding foreigners included in the control group increased. As a consequence, a negative difference in differences test result was obtained with a value close to the first test result. Therefore, both tests show a slight negative impact of the visa waiver for Ukrainian citizens on their employment in Poland. In the long term, the visa-free regime may result in a larger outflow of Ukrainians from Poland to other European Union countries where they can find higher wages and salaries. In the future, by "chain migration", the Ukrainian citizens can reduce the monetary and non-monetary costs associated with migrating to countries more distant from their place of residence than Poland. Due to this, the investment in the form of migration to a country with higher earnings will bring them a higher present value of net benefits of migration. 
Table 4. The difference in differences test concerning declarations of the intention to entrust work to citizens of Ukraine (treatment group) and citizens of Armenia, Belarus and Russia (control group) registered in Poland in the second half of 2016 and the second half of 2017 in \%

\begin{tabular}{|l|c|c|c|}
\hline \multicolumn{1}{|c|}{ Specification } & $\begin{array}{c}\text { Second half } \\
\text { of } \mathbf{2 0 1 6}\end{array}$ & $\begin{array}{c}\text { Second half } \\
\text { of } \mathbf{2 0 1 7}\end{array}$ & $\begin{array}{c}\text { The difference between the second half } \\
\text { of } \mathbf{2 0 1 7} \text { and the second half of 2016 }\end{array}$ \\
\hline $\begin{array}{l}\text { Treatment group } \\
\text {-citizens of Ukraine }\end{array}$ & 95.42 & 92.41 & -3.01 \\
\hline $\begin{array}{l}\text { Control group } \\
\text { citizens of Armenia, } \\
\text { Belarus and Russia }\end{array}$ & 2.72 & 4.43 & 1.71 \\
\hline $\begin{array}{l}\text { The difference between } \\
\text { the treatment group } \\
\text { and the control group }\end{array}$ & 92.70 & 87.98 & $\mathbf{- 4 . 7 2}$ \\
\hline
\end{tabular}

Source: own elaboration based on the data from Table 3.

\section{Conclusion}

Economic migration is a specific form of investment in human capital. A person will opt for migration only if the present value of net benefits of migration is greater than zero. This amount can be determined by calculating the difference between the earned income from future and current work as well as monetary and non-monetary costs of migration, such as costs of obtaining information about future work, travel costs to the country of destination, or psychic costs associated with leaving close persons. Foreigners can work in Poland on the basis of a work permit. In addition, employers may employ citizens of Ukraine, Armenia, Belarus, Georgia, Moldova and Russia based on a declaration of the intention to entrust work to a foreigner, registered at the appropriate poviat labour office. The conducted research showed that in recent years the number of type A work permits issued, as well as the number of registered declarations of the intention to entrust work to a foreigner, has been growing systematically. The vast majority of type A work permits (over 80\%) and declarations (over 90\%) were issued to Ukrainian citizens.

Two difference in differences tests carried out suggest that in the short term (6 months), the lifting of the visa requirement for Ukrainian citizens had a slightly negative impact on their employment in Poland. In the following years, the observed effects may deepen as, for example, by "chain migration", Ukrainians reduce the monetary and non-monetary costs of migration to countries with higher earnings, further away from their place of residence than Poland. Then they will receive a higher present value of net benefits of migration to these countries. Available statistical data, however, does not allow this claim to be verified. As a result of changes in laws regarding foreigners' employment in Poland, data for 2018 has become impossible to compare with data from the previous years. On their basis, it can only be concluded that in 2018 in Poland: 
- 315.9 thousand type A work permits were issued, of which $73.4 \%$ were obtained by Ukrainian citizens, and citizens of Armenia, Belarus and Russia received 6.0\%;

- 1582.2 thousand declarations to entrust work to a foreigner were registered, of which 91.4\% concerned citizens of Ukraine and $4.5 \%$ citizens of Armenia, Belarus and Russia;

- 121.4 thousand seasonal work permits were issued, of which Ukrainian citizens received 98.8\%, and citizens of Armenia, Belarus and Russia- $0.5 \%$.

\section{References}

Besley T., Case, A. (2000). Unnatural experiments? Estimating the incidence of endogenous policies. Economic Journal, 110: F672-F694.

Borjas, G. J. (1987). Self-selection and the earnings of immigrants. The American Economic Review, 77(4): 531-553.

Borjas, G. J. (1994). The economics of immigration. Journal of Economic Literature, 32(4): 1667-1717.

Borjas, G. J. (2016). Labor economics, seventh edition. New York: McGraw Hill Education.

Ehrenberg, R. G., Smith, R. S. (2012). Modern labor economics: theory and public policy, eleventh edition. Boston: Prentice Hall.

Filer, R. K., Hamermesh, D. S., Rees, A. E. (1996). The economics of work and pay, sixth edition. New York: HarperCollins College Publishers.

IAR (2017). Zniesienie wiz dla Ukraińców. To wyzwanie dla polskiego rynku pracy. Available at: https://www.polskieradio.pl/42/275/Artykul/1775579,Zniesienie-wiz-dla-UkraincowTo-wyzwanie-dla-polskiego-rynku-pracy [access date: 10.05.2019].

McConnell, C. R., Brue, S. L., Macpherson, D. A. (2006). Contemporary labour economics, seventh edition. New York: McGraw-Hill Irwin.

Meyer, B. D. (1995). Natural and quasi-experiments in economics. Journal of Business \& Economic Statistics, 13(2): 151-161.

Mincer, J. (1978). Family migration decisions. Journal of Political Economy, 86(5): 749-773.

Ośrodek Studiów Wschodnich (2017). Zniesienie obowiąku wizowego wobec obywateli Ukrainy-konsekwencje migracyjne dla Unii Europejskiej. Ekspertyza Ośrodka Studiów Wschodnich. Warszawa.

Regulation (EU) 2017/850 of the European Parliament and of the Council of 17 May 2017 (2017) amending Regulation (EC) No 539/2001 listing the third countries whose nationals must be in possession of visas when crossing the external borders and those whose nationals are exempt from that requirement (Ukraine). OJ L 133, 22.5.2017: 1-3.

Rozporządzenie (2009). Rozporzadzenie Ministra Pracy i Polityki Społecznej z dnia 29 stycznia 2009 r. w sprawie przypadków, w których zezwolenie na pracę cudzoziemca jest wydawane bez względu na szczegótowe warunki wydawania zezwoleń na pracę cudzoziemców, t.j. Dz.U. z 2015 r., poz. 97 [consolidated text: Journal of Laws of 2015, item 97]. 
Rozporządzenie (2015a). Rozporzadzenie Ministra Pracy i Polityki Spotecznej z dnia 1 kwietnia 2015 r. w sprawie wydawania zezwolenia na prace cudzoziemca, Dz.U. z 2015 r., poz. 543 [Journal of Laws of 2015, item 543].

Rozporządzenie (2015b). Rozporzadzenie Ministra Pracy i Polityki Spotecznej z dnia 21 kwietnia 2015 r. w sprawie przypadków, w których powierzenie wykonywania pracy cudzoziemcowi na terytorium Rzeczypospolitej Polskiej jest dopuszczalne bez konieczności uzyskania zezwolenia na prace, Dz.U. z 2015 r., poz. 588 [Journal of Laws of 2015, item 588].

Rozporządzenie (2017a). Rozporzadzenie Ministra Rodziny, Pracy i Polityki Społecznej $z$ dnia 7 grudnia 2017 r. w sprawie wydawania zezwolenia na prace oraz wpisu oświadczenia o powierzeniu wykonywania pracy cudzoziemcowi do ewidencji oświadczeń, Dz.U. z 2017 r., poz. 2345 [Journal of Laws of 2017, item 2345].

Rozporządzenie (2017b). Rozporzadzenie Ministra Rodziny, Pracy i Polityki Spotecznej z dnia 8 grudnia 2017 r. w sprawie podklas działalności wedtug Polskiej Klasyfikacji Działalności (PKD), w których wydawane sa zezwolenia na prace sezonowa cudzoziemca, Dz.U. z 2017 r., poz. 2348 [Journal of Laws of 2017, item 2348]

Rozporządzenie (2017c). Rozporządzenie Ministra Rodziny, Pracy i Polityki Społecznej z dnia 8 grudnia 2017 r. w sprawie państw, do których obywateli stosuje się niektóre przepisy dotyczace zezwolenia na pracę sezonowa oraz przepisy dotyczace oświadczenia o powierzeniu wykonywania pracy cudzoziemcowi, Dz.U. z 2017 r., poz. 2349 [Journal of Laws of 2017, item 2349].

Schwartz, A. (1973). Interpreting the effect of distance on migration. Journal of Political Economy, 81(5): 1153-1169.

Sjaastad L.A. (1962). The costs and returns of human migration. Journal of Political Economy, 70(5): 80-93.

Tharenou, P., Donohue, R., Cooper, B. (2007). Management research methods. New York: Cambridge University Press.

Ustawa (2004). Ustawa z dnia 20 kwietnia 2004 r. o promocji zatrudnienia $i$ instytucjach rynku pracy, t.j. Dz.U. z 2018 r., poz. 1268 [consolidated text: Journal of Laws of 2018, item 1268].

\section{Streszczenie}

Obywatele Ukrainy mogą podejmować pracę w Polsce na podstawie zezwolenia na pracę lub zarejestrowanego oświadczenia pracodawcy o powierzeniu wykonywania pracy cudzoziemcowi. Rozporządzeniem Parlamentu Europejskiego i Rady (UE) 2017/850 z dnia 17 maja 2017 r. zostali oni zwolnieni z wymogu posiadania wizy przy przekraczaniu zewnętrznych granic Unii Europejskiej. Rozporządzenie to weszło w życie 11 czerwca 2017 r. i dotyczy pobytów krótkoterminowych, trwających do 90 dni w okresie 180 dni. Według niektórych przedstawicieli organizacji pracodawców przepisy o ruchu bezwizowym są niekorzystne dla polskich przedsiębiorstw, gdyż obywatele Ukrainy zamiast poszukiwać pracy w Polsce będą wybierać inne kraje Unii Europejskiej, w których mogą uzyskać wyż- 
sze wynagrodzenia za pracę. Celem tego artykułu jest ustalenie czy zniesienie obowiązku wizowego wobec obywateli Ukrainy wpłynęło na podejmowanie przez nich pracy w Polsce w ciągu 6 miesięcy od wprowadzenia nowych przepisów, tj. od czerwca do grudnia 2017 r. Badania przeprowadzone metodą eksperymentu naturalnego sugerują, że w krótkim okresie zniesienie obowiązku wizowego wobec obywateli Ukrainy miało niewielki negatywny wpływ na podejmowanie przez nich pracy w Polsce.

Słowa kluczowe: zatrudnienie, migracja, cudzoziemiec, rynek pracy 